\title{
Proses Transformasi Visual ke Simbolik Mahasiswa dalam Menyelesaikan Masalah Luas Daerah di Bawah Kurva
}

\author{
Octavina Rizky Utami Putri ${ }^{{ }^{*}}$, Minatun Nadlifah ${ }^{2}$ \\ ${ }^{1,2}$ Program Studi Pendidikan Matematika, Universitas Muhammadiyah Malang \\ *octavina@umm.ac.id
}

\begin{abstract}
Abstrak
Representasi matematis merupakan bentuk interpretasi dari ide penyelesaian masalah matematika. Proses representasi matematis sangat penting diperhatikan, terutama dalam melakukan transformasi antar bentuk representasi, karena berdampak pada solusi akhir yang diperoleh. Penelitian ini bertujuan untuk mendeskripsikan alur berpikir mahasiswa dalam melakukan proses transformasi dari representasi visual ke simbolik. Penelitian deskriptif ini dilaksanakan dengan pendekatan kualitatif. Tahap penelitian ini meliputi menyiapkan tes representasi dan pedoman wawancara, memberikan tes pada 48 mahasiswa, melakukan wawancara pada mahasiswa terpilih berdasarkan ketepatan representasi matematis yang dihasilkan, dan evaluasi. Evaluasi dilakukan dengan mereduksi hasil tes representasi yang tidak tepat, menyajikan data representasi visual dan simbolik serta proses transformasinya, dan menyimpulkan proses transformasi. Hasil proses transformasi representasi visual ke simbolik dalam menyelesaikan masalah luas daerah di bawah kurva dilakukan dengan alur berpikir yaitu menerjemahkan bentuk daerah poligon menjadi kumpulan persegi panjang, menentukan lebar dan panjang partisi daerah poligon, dan menentukan luas daerah poligon sebagai kumpulan persegi panjang. Dalam menentukan luas daerah sebagai kumpulan persegi panjang, terdapat dua proses yang berbeda, yakni membuat model matematis dalam bentuk notasi sigma dan penjumlahan. Penelitian ini memberikan wawasan tentang alur berpikir dalam mengubah antar bentuk representasi matematis, harapannya dapat mengantisipasi terjadinya kesalahan dalam menyelesaikan masalah luas di bawah kurva.
\end{abstract}

Kata kunci: representasi matematis, simbolik, tranformasi, visual

\begin{abstract}
Mathematical representation is an idea interpretation form of solving mathematical problems. The process of mathematical representation is essential to pay attention to, especially in carrying out transformations between forms of representation, because it impacts the final solution obtained. This study describes the flow of students' thinking in carrying out the transformation process from visual to symbolic representation. This descriptive research was carried out with a qualitative approach. This research phase includes preparing representation tests and interview guidelines, giving tests to 48 students, conducting interviews with selected students based on the accuracy of the mathematical representations produced, and evaluation. The evaluation is carried out by reducing the results of the incorrect representation test, presenting visual and symbolic representation data and the transformation process, and concluding the transformation process. The result of the transformation process from visual to symbolic representation in solving the problem of the area under the curve is carried out with a flow of thought, namely translating the shape of the polygon area into a collection of rectangles, determining the width and length of the partition of the polygon area, and determining the area of the polygon area as a collection of rectangles. In determining the area as a collection of rectangles, there are two different processes, making a mathematical model in the form of sigma notation and addition. This study provides insight into the flow of thinking in changing between forms of mathematical representation in the hope that it can anticipate errors in solving the broad problem under the curve.
\end{abstract}

Keywords: mathematical representation, symbolic, transformation, visual 


\section{Pendahuluan}

Representasi matematis merupakan bentuk interpretasi ide-ide matematika sebagai upaya dalam menyelesaikan masalah. Representasi matematis dalam berbagai bentuk dan cara, menunjukkan kegiatan berpikir dalam mengkomunikasikan ide-ide matematika (Astuti, 2017; Hutagaol, 2013). Representasi matematis ini dapat berupa visual, simbolik, maupun verbal. Representasi matematis secara visual seperti gambar, grafik, atau tabel. Representasi matematis secara simbolik berupa notasi, numerik, atau model matematis. Representasi matematis secara verbal dapat berupa kata-kata (Lestari \& Yudhanegara, 2017; Sabirin, 2014).

Representasi visual, simbolik, dan verbal merupakan komponen yang saling berkaitan dan mendukung dalam menyelesaikan masalah matematis (Boaler, Chen, Williams, \& Cordero, 2016). Sebagai contoh, penyelesaian aritmatika sederhana melibatkan representasi visual maupun verbal untuk membangun solusi secara simbolik (Inglis, Attridge, \& Batchelor, 2011). Contoh lain, pada penyelesaian masalah kalkulus dalam menentukan luas daerah di bawah kurva. Visualisasi grafik sangat membantu mahasiswa dalam membuat persamaan matematis yang memuat simbol integral (Septian, Darhim, \& Prabawanto, 2020). Oleh sebab itu, diperlukan kemampuan individu untuk dapat menyelesaikan masalah dengan berbagai bentuk representasi matematis guna mendukung penyelesaian masalah yang tepat.

Kemampuan translasi matematis masing-masing individu menjadi prasyarat keberhasilan dalam merepresentasikan solusi matematis, khususnya dalam mentransformasi antar komponen representasi matematis (M. J. Bossé, Adu-Gyamfi, \& Cheetham, 2011). Kemampuan dalam melakukan transformasi dari suatu bentuk representasi ke bentuk lain sangat penting untuk membangun pemikiran konseptual (Rahmawati, Purwanto, Subanji, Hidayanto, \& Anwar, 2017). Hal ini didukung penelitian lain bahwa representasi visual dan verbal memberikan kontribusi pada pemahaman konsep numerik (Göbel, Moeller, Pixner, Kaufmann, \& Nuerk, 2014). Berpikir melalui representasi visual memberikan pengaruh positif terhadap pemahaman konseptual dalam pemecahan masalah matematis (Abdullah, Zakaria, \& Halim, 2012; Trance, Marapo, \& Pornel, 2012).

Pengalaman belajar diperlukan untuk menentukan keberhasilan dalam menginterpretasikan berbagai bentuk representasi matematis (Fyfe, McNeil, Son, \& Goldstone, 2014). Berdasarkan observasi pada perkuliahan Kalkulus sebelumnya, diperoleh informasi bahwa 23 dari 48 mahasiswa mampu menggambar kurva dengan tepat. Selanjutnya, hanya terdapat 9 dari 23 mahasiswa yang dapat membuat kurva secara tepat dan menyelesaikan luas daerah di bawah kurva dengan prosedur yang memuat simbol secara tepat. Hal ini disebabkan 
karena terjadi kesalahan saat menerjemahkan bentuk partisi poligon menjadi model luas daerah di bawah kurva. Demikian pula pada penelitian terdahulu bahwa kurangnya pemahaman dalam menggambar kurva mengakibatkan kesalahan dalam menentukan luas daerah di bawah kurva (Mataheru, Huwaa, \& Matitaputty, 2021). Kesulitan menggambar grafik juga mengakibatkan kesalahan dalam melakukan prosedur matematis (Utari, Septy, \& Hutauruk, 2021). Oleh karena itu, penting sekali untuk menggali informasi lebih lanjut terkait kemampuan representasi mahasiswa dalam mentransformasi dari bentuk visual ke simbolik.

Keterlibatan representasi visual memberikan kemudahan dalam menyelesaikan masalah hingga menemukan solusi akhir (Boonen, Van Wesel, Jolles, \& Van der Schoot, 2014). Representasi matematis secara visual berperan penting dalam keterkaitan ide abstrak matematika dan representasi empiris seseorang (David \& Tomaz, 2012). Keterlibatan visualiasi dalam penyelesaian masalah matematis memberikan dampak yang baik untuk membangun representasi simbolik daripada melakukan hafalan. Penyelesaian dalam bentuk simbolik sangat mendukung dalam melakukan prosedur perhitungan, namun representasi simbolik yang berlebihan mengakibatkan kurangnya kreativitas mahasiswa (Boaler et al., 2016; Luca \& Pesenti, 2011).

Kajian tentang representasi matematis banyak berfokus pada deskripsi kemampuan, jenis kesalahan dan pengaruh representasi matematis, baik secara visual maupun simbolik (Huda, Musdi, \& Nari, 2019; Ikashaum, Mustika, Wulantina, \& Cahyo, 2021; Komala, 2020; Nurfitriyanti, Kusumawardani, \& Lestari, 2020; Setiawati, Widadah, Nurmala, \& Agustina, 2020). Kajian tentang alur berpikir mahasiswa dalam proses transformasi dari satu bentuk representasi matematis ke bentuk representasi lainnya belum ditemukan. Hal ini penting untuk dilakukan karena representasi dipandang sebagai bentuk interpretasi pemikiran individu terhadap suatu masalah, yang digunakan sebagai alat untuk menemukan solusi masalah tersebut (Sabirin, 2014).

Dengan demikian, penelitian ini bertujuan untuk mendeskripsikan alur berpikir mahasiswa dalam melakukan representasi visual dan simbolik beserta proses transformasinya. Penelitian ini berguna untuk meminimalisir terjadinya kesalahan representasi simbolik berdasarkan visualisasi yang diberikan.

\section{Metode}

Penelitian dilakukan menggunakan pendekatan kualitatif dengan jenis penelitian deskriptif untuk menggali informasi alur berpikir mahasiswa dalam melakukan transformasi visual ke simbolik, guna mengantisipasi terjadinya kesalahan dalam menyelesaikan masalah 
luas daerah di bawah kurva. Adapun partisipan dalam penelitian adalah 48 mahasiswa Pendidikan Matematika, terdiri dari 13 laki-laki dan 35 perempuan, yang menempuh perkuliahan Kalkulus Integral. Tahap penelitian ini meliputi (1) perencanaan, yaitu menyiapkan tes representasi dan pedoman wawancara, (2) pelaksanaan, yaitu memberikan tes pada mahasiswa, melakukan wawancara pada mahasiswa terpilih berdasarkan ketepatan representasi matematis yang dihasilkan, (3) evaluasi, yaitu mereduksi hasil tes yang representasinya tidak tepat, menyajikan data representasi visual dan simbolik serta proses transformasinya, dan menyimpulkan proses transformasi.

Data penelitian diperoleh dari dua jenis instrumen, yakni lembar tes representasi luas daerah di bawah kurva dan pedoman wawancara. Instrumen lembar tes representasi disusun sebagai upaya untuk memperoleh gambaran kemampuan representasi mahasiswa secara tertulis. Lembar tes memuat dua soal uraian tentang menentukan luas daerah di bawah kurva. Instrumen pedoman wawancara disusun sebagai acuan untuk mengekplorasi proses transformasi representasi visual ke simbolik. Lembar tes dan pedoman wawancara divalidasi oleh dosen Pendidikan Matematika dengan hasil validasi pada kategori valid. Pengumpulan data dilakukan dengan memberikan tes pada 48 mahasiswa, selanjutnya melakukan wawancara pada mahasiswa terpilih berdasarkan ketepatan representasi matematis yang dihasilkan pada jawaban tes.

Analisis data dilakukan secara induktif berdasarkan alur yang dikemukakan oleh Creswell (2012). Adapun langkah-langkah analisis data penelitian dijabarkan sebagai berikut (1) mengklasifikasi hasil tes berdasarkan deskripsi kemampuan representasi pada Tabel 1 dan transkrip hasil wawancara, (2) membaca keseluruhan data, (3) melakukan coding data dari hasil penyelesaian tes representasi dan hasil wawancara, (4) menerapkan proses coding untuk mendapatkan gambaran proses transformasi representasi visual ke simbolik, (5) mendeskripsikan temuan-temuan, (6) melakukan interpretasi data dengan menafsirkan temuan yang dikaitkan dengan kajian kepustakaan dan hasil-hasil penelitian yang relevan.

Tabel 1. Indikator kemampuan representasi

\begin{tabular}{cll}
\hline Jenis Representasi & \multicolumn{1}{c}{ Indikator Kemampuan Representasi } \\
\hline Visual & 1. & Menggambar kurva sesuai domain secara tepat \\
& 2. Menggambar poligon dalam atau luar secara tepat \\
& 3. Membuat partisi poligon secara proporsional \\
\hline Simbolik & 1. Membuat model matematis dengan simbol yang tepat \\
& 2. Melakukan prosedur penyelesaian model matematis dengan \\
& 3imbol yang tepat \\
& 3. Menentukan hasil akhir dengan simbol yang tepat \\
\hline
\end{tabular}


Indikator kemampuan representasi mengacu pada proses representasi matematis yakni mengeksplorasi sumber, menyusun pengetahuan awal, membangun representasi target, dan menentukan kesepadanan (Bossé, Adu-Gyamfi, \& Chandler, 2014; Chandler, Adu-Gyamfi, 2016). Eksplorasi sumber dengan cara menggambar kurva sesuai domain secara tepat. Penyusunan pengetahuan awal dengan menggambar poligon secara tepat dan membuat partisinya secara proporsional. Membangun representasi target melalui penyusunan model matematis dengan simbol yang tepat. Menentukan kesepadanan dengan melakukan prosedur penyelesaian model matematis dengan simbol yang tepat serta hasil akhir dengan simbol yang tepat.

\section{Hasil Penelitian}

\section{Representasi Visual}

Data representasi visual diperoleh dari penyelesaian masalah dalam menentukan luas daerah di bawah kurva. Mahasiswa diminta untuk menentukan luas di bawah kurva $y=-\frac{1}{2} x+$ 5 dengan batas interval $[-2,0]$. Hasil penyelesaian masalah mahasiswa dalam menentukan luas daerah di bawah kurva diawali dengan penyelesaian secara visual. Mahasiswa menggambar kurva dan dilanjutkan dengan menggambar poligon dalam atau luar. Namun, tidak semua mahasiswa mampu merepresentasikan visual secara tepat. Hal ini disebabkan karena terdapat kesalahan dalam menggambar kurva maupun poligon. Kesalahan menggambar kurva maupun poligon ditunjukkan dengan tidak tepat dalam menetukan titik potong kurva terhadap sumbu- $x$ dan sumbu- $y$, tidak tepat dalam menentukan batas interval domain, dan tidak proporsional dalam menggambar partisi poligon.

Data representasi visual dalam penelitian ini dipilih berdasarkan hasil gambar poligon yang tepat. Bentuk representasi visual ini berdasarkan deskripsi kemampuan representasi visual antara lain (1) menggambar kurva dengan batas interval domain secara tepat, (2) membagi daerah di bawah kurva sebanyak $n$ partisi, (3) menggambar poligon dalam atau luar secara tepat, dan (4) membuat partisi daerah di bawah kurva secara proporsional.

Gambar 1 merupakan contoh penyelesaian masalah luas daerah di bawah kurva yang benar oleh mahasiswa. Mahasiswa mengawali penyelesaiannya dengan menggambar poligon dalam. 


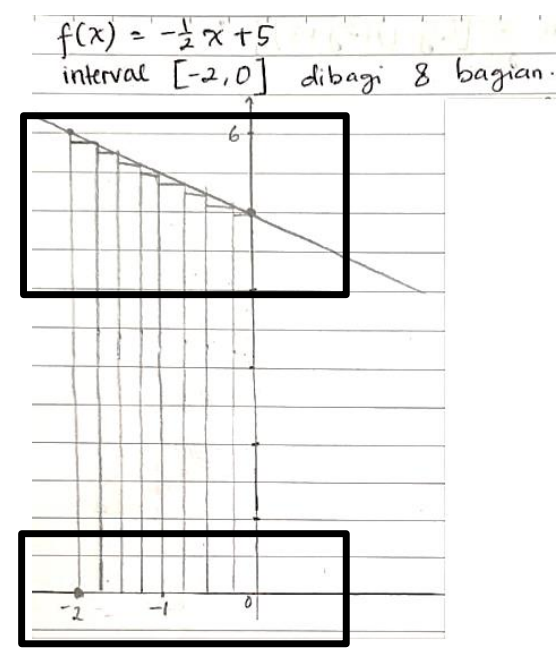

Gambar 1. Poligon dalam $y=-\frac{1}{2} x+5 y$

Pada gambar 1, mahasiswa mampu menggambar kurva $y=-\frac{1}{2} x+5 y$ secara tepat dengan titik potong terhadap sumbu- $y$ yaitu $(0,5)$. Kurva digambar dengan batas interval domain yaitu $[-2,0]$. Berdasarkan poligon dalam yang digambar, mahasiswa membagi daerah di bawah kurva menjadi 8 partisi dengan gambar yang proporsional. Hasil penyelesaian masalah secara visual ini selanjutnya digunakan untuk menentukan luas daerah di bawah kurva dalam bentuk simbolik.

\section{Representasi Simbolik}

Hasil penyelesaian masalah selanjutnya dalam menentukan luas daerah di bawah kurva adalah penyelesaian secara simbolik. Mahasiswa mampu membuat model matematis luas daerah di bawah kurva berdasarkan poligon yang telah digambar hingga menemukan hasil akhir dengan tepat. Namun, tidak semua mahasiswa mampu merepresentasikan simbolik secara tepat. Hal ini disebabkan karena masih terdapat beberapa kesalahan. Kesalahan-kesalahan tersebut meliputi tidak tepat menentukan panjang partisi poligon $\Delta x$, tidak tepat dalam menetukan batas titik partisi, tidak tepat dalam membuat model luas daerah di bawah kurva, serta tidak tepat dalam menghitung hasil akhir dengan simbol yang benar.

Penyelesaian masalah dalam bentuk representasi simbolik dalam penelitian dipilih berdasarkan hasil model luas daerah di bawah kurva serta penyelesaiannya secara tepat. Bentuk representasi simbolik ini ditunjukkan berdasar deskripsi kemampuan representasi simbolik antara lain (1) membuat model matematis luas daerah di bawah kurva dengan simbol matematika dasar, aljabar, dan numerik yang tepat, (2) melakukan prosedur penyelesaian model matematis dengan simbol matematika dasar, aljabar, dan numerik yang tepat, dan (3) menentukan hasil akhir dengan simbol matematika dasar dan numerik yang tepat. 
Gambar 2 merupakan contoh penyelesaian masalah luas daerah di bawah kurva dengan notasi sigma oleh mahasiswa. Mahasiswa memberikan model matematis dalam bentuk notasi sigma, berdasarkan poligon yang dibuat, serta menyelesaikannya hingga menemukan hasil akhir dengan simbol yang tepat.

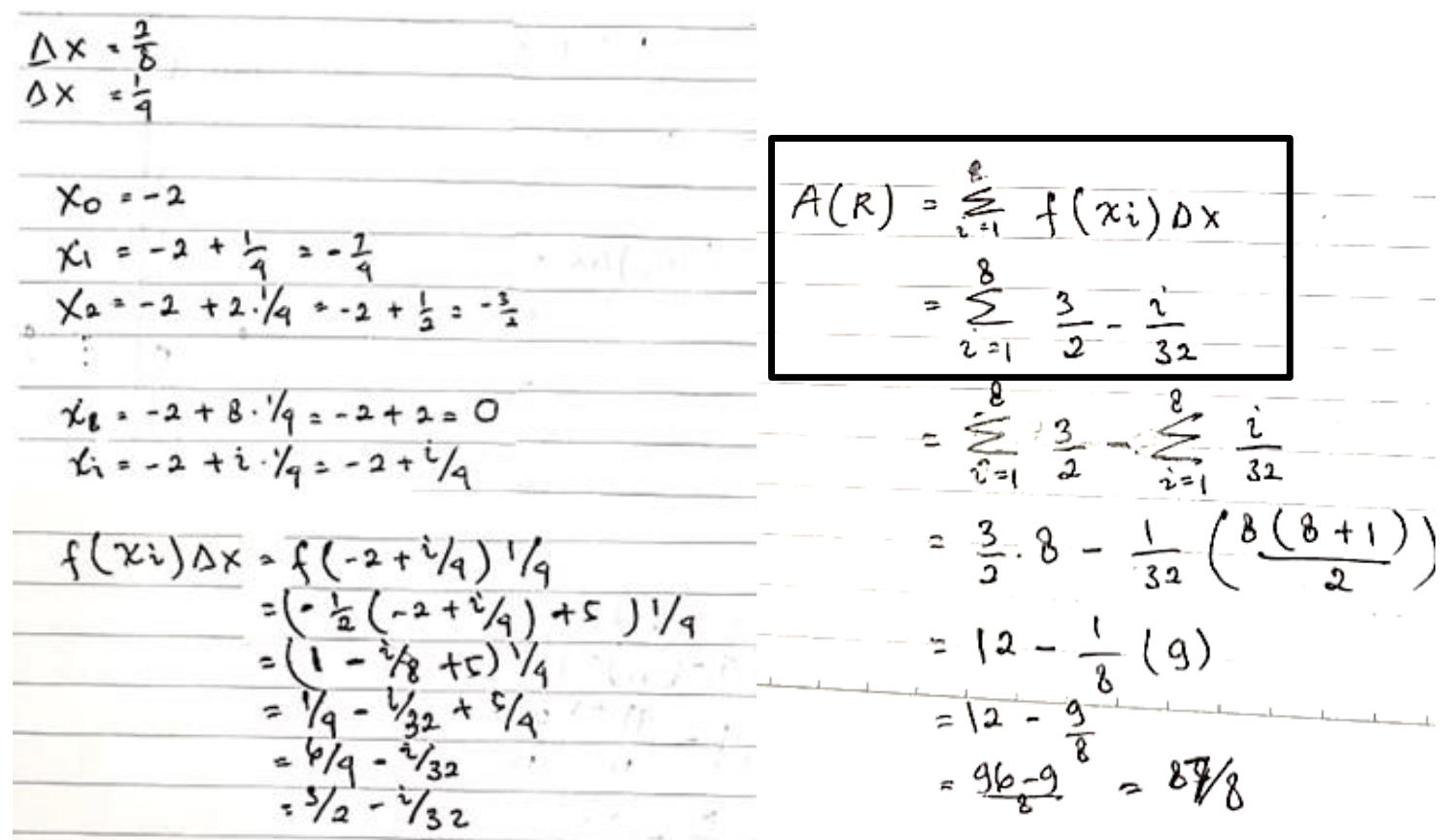

Gambar 2. Penyelesaian dengan membuat model matematis notasi sigma

Sedangkan Gambar 3 merupakan contoh penyelesaian masalah luas daerah di bawah kurva dengan menjumlahkan luas partisi secara langsung.

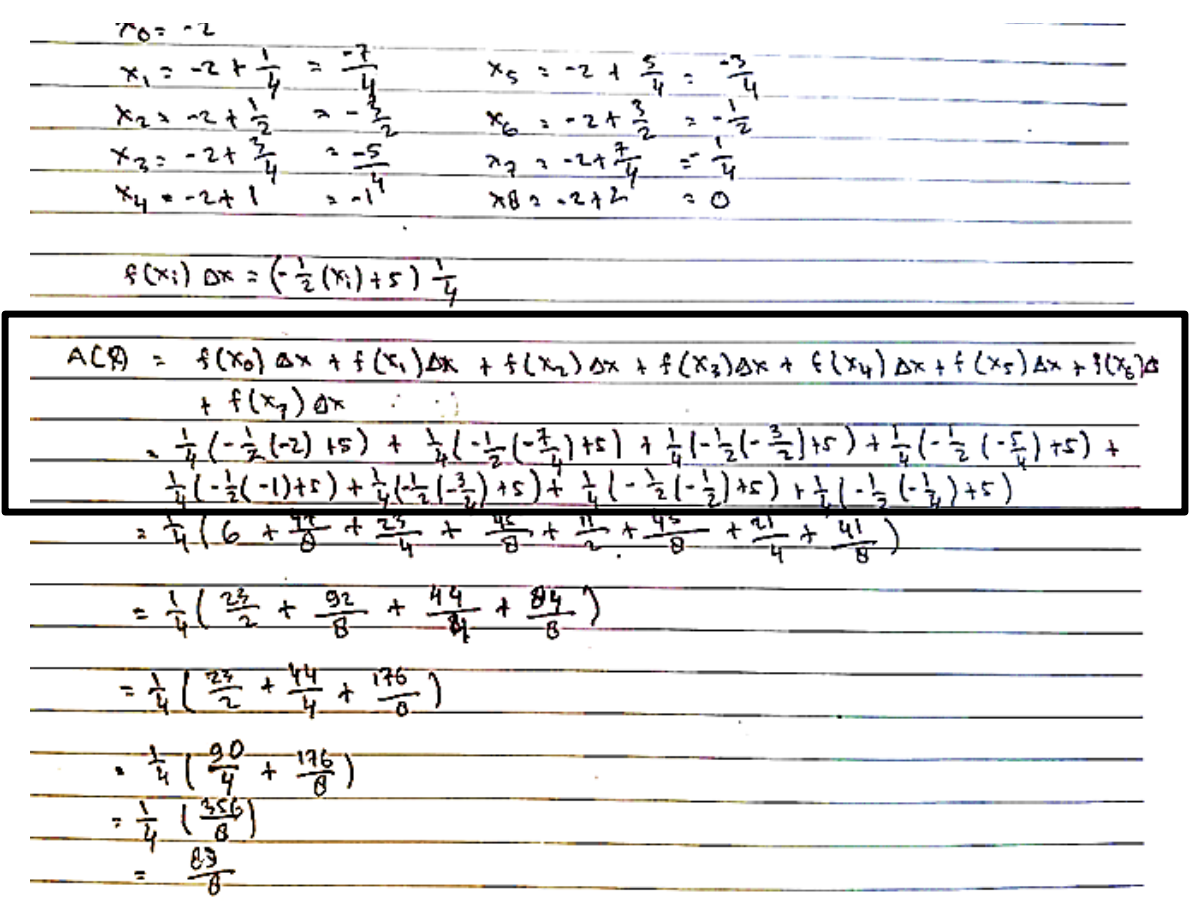

Gambar 3. Penyelesaian dengan membuat model matematis notasi jumlah 
Berdasarkan Gambar 2 dan 3, mahasiswa mampu menyelesaikan luas daerah di bawah kurva dengan melibatkan simbol operator aritmetika, operator relasi, variabel, bilangan secara tepat. Mahasiswa juga mampu melakukan prosedur penyelesaian model matematis dengan simbol operator aritmetika, operator relasi, variabel, serta bilangan secara tepat. Demikian juga dalam menentukan hasil akhir, mahasiswa merepresentasikan simbol operator relasi dan bilangan rasional secara tepat.

Perbedaan penyelesaian Gambar 2 dan Gambar 3 terdapat pada prosedur penyelesaiannya yaitu menggunakan notasi sigma dan notasi jumlah. Pada prosedur penyelesaian notasi sigma, mahasiswa membuat rumus umum luas daerah di bawah kurva sebelum menentukan luasnya. Berbeda halnya dengan prosedur penyelesaian notasi jumlah, mahasiswa menentukan luas masing-masing partisi daerah di bawah kurva kemudian menjumlahkan semua luas partisinya.

\section{Proses Transformasi Representasi Visual ke Simbolik}

Proses transformasi dari representasi visual ke simbolik memiliki peranan penting dalam menyelesaikan masalah luas daerah di bawah kurva. Proses ini yang menentukan ketepatan dalam membangun model matematis secara simbolik. Berikut gambaran proses transformasi representasi visual ke simbolik.

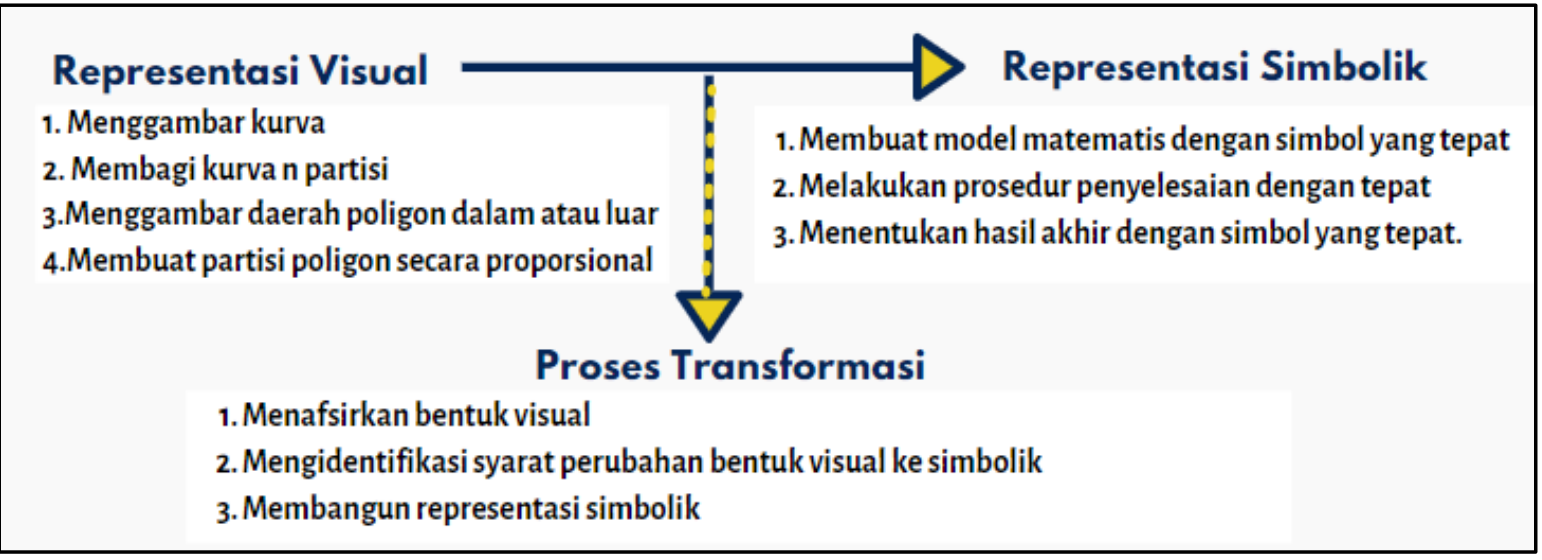

Gambar 4. Proses Transformasi Representasi Visual ke Simbolik

Proses transformasi pada gambar 4 merupakan gambaran umum dari transformasi representasi secara visual menjadi simbolik. Terdapat 3 tahap dalam proses transformasi antara lain menafsirkan bentuk visual, mengidentifikasi syarat perubahan bentuk visual ke simbolik, dan membangun representasi simbolik.

Tahap pertama, menafsirkan bentuk visual. Mahasiswa menerjemahkan bentuk poligon menjadi kumpulan persegi panjang. Mahasiswa menganalogikan luas daerah di bawah kurva dapat disusun dari beberapa luas daerah persegi panjang. Artinya, semakin banyak luas daerah 
persegi panjang yang dibuat semakin mendekati luas daerah di bawah kurva. Hal ini diperkuat oleh kutipan wawancara berikut:

Peneliti : Berdasarkan gambar kurva yang dibentuk dari persamaan $y=-\frac{1}{2} x+5$ dan dibatasi oleh interval $[-2,0]$, bagaimana Saudara menentukan luas daerah di bawah kurva tersebut?

Mahasiswa : sesuai dengan pertanyaan soal, saya membagi interval [-2,0] dalam delapan bagian yang sama... setelah itu, daerah di bawah kurva saya hitung sebagai luas dari delapan persegi panjang yang ada di bawah kurva dan dalam batas interval yang diberikan

Peneliti : Menurut Saudara, apakah luas daerah di bawah kurva sama dengan luas delapan persegi panjang yang ada dibawah kurva?

Mahasiswa : hmmmm.... tidak sama Bu

Peneliti : Mengapa tidak sama?

Mahasiwa : karena masih ada ruang kosong di bawah kurva yang tidak menjadi bagian dari delapan persegi panjang yang ada.

Peneliti : Menurut Saudara, bagaimana cara mengurangi ruang kosong di bawah kurva tersebut?

Mahasiswa : dengan membagi interval $[-2,0]$ ke dalam banyak bagian yang sama sehingga akan terbentuk banyak persegi panjang dengan lebar yang saling berhimpit.

Tahap kedua, mahasiswa mengidentifikasi syarat perubahan bentuk visual ke simbolik. Jika luas daerah di bawah kurva dianalogikan sebagai beberapa luas daerah persegi panjang, maka diperlukan panjang dan lebar persegi panjang. Tujuannya adalah agar dapat ditentukan luas daerah persegi panjang. Hasil identifikasi syarat perubahan bentuk visual ke simbolik ini yakni menentukan lebar sebagai $\Delta x_{i}=\frac{\text { batas kanan-batas kiri }}{\text { banyak persegi panjang }}$ dan panjang sebagai $f_{x_{i}}$. Temuan ini diperkuat berdasarkan kutipan wawancara berikut.

Peneliti : Bagaimana cara Saudara menentukan panjang dan lebar dari persegi panjang di bawah kurva?

Mahasiswa : karena interval [-2,0] dibagi menjadi delapan bagian yang sama besar, maka lebar persegi panjangnya sama dengan 0 tiap dikurangi -2 kemudian dibagi 8 , sedangkan panjang dari persegi panjang sama dengan nilai $y=-\frac{1}{2} x_{i}+5$ dengan i mulai dari nol sampe dengan 8.

Tahap ketiga, mahasiswa membangun representasi simbolik dengan cara menyusun model matematis luas daerah di bawah kurva sebagai kumpulan luas persegi panjang. Luas masing-masing persegi panjang adalah $L_{i}=f_{x_{i}} \cdot \Delta x_{i}$, sehingga diperoleh luas daerah di bawah kurva adalah sebagai berikut.

$$
L=L_{1}+\cdots+L_{n}=\left(f_{x_{1}} \cdot \Delta x_{1}\right)+\cdots+\left(f_{x_{n}} \cdot \Delta x_{n}\right)=\sum_{i=1}^{n}\left(f_{x_{i}} \cdot \Delta x\right)
$$


Model matematis di atas diselesaikan hingga ditemukan hasil akhir dengan melibatkan simbolsimbol matematis. Simbol-simbol tersebut antara lain simbol matematika dasar, aljabar, dan numerik.

Proses transformasi tersebut merupakan bentuk temuan lain dari proses antar representasi matematis yakni mengeksplorasi sumber, menyusun pengetahuan awal, membangun representasi target, dan menentukan kesepadanan. Setiap tahapan pada proses transformasi yang ditemukan digunakan sebagai acuan untuk mengantisipasi terjadinya kesalahan dalam menyelesaikan masalah di bawah kurva, khusunya dalam menerjemahkan daerah bawah kurva menjadi model luas daerah di bawah kurva.

\section{Pembahasan}

Bentuk penyelesaian masalah dalam menentukan luas daerah di bawah kurva diawali dengan merepresentasikan solusi secara visual, yaitu dalam bentuk poligon. Poligon yang direpresentasikan berupa poligon dalam maupun luar. Penyusunan poligon ini merupakan hal penting untuk diperhatikan, terutama dalam membedakan tinggi poligon dalam dan luar. Demikian pula pada penelitian terdahulu bahwa penting bagi mahasiswa untuk dapat menentukan tinggi poligon yang berupa nilai fungsi $f\left(x_{i-1}\right)$ untuk poligon dalam dan $f\left(x_{i}\right)$ untuk poligon luar (Tasman, Ahmad, \& Suherman, 2018). Studi lain juga menyampaikan bahwa pemisalan nilai $x_{0}$ berdampak pada penentuan tinggi poligon (Rahimah, 2012).

Bentuk penyelesaian masalah selanjutnya adalah membuat model matematis berdasarkan poligon yang digambar dan menyelesaikannya hingga menemukan hasil akhir. Model matematis dan penyelesaiannya ini memuat simbol-simbol matematis. Hal ini relevan dengan penelitian terdahulu bahwa transformasi antar bentuk representasi berkaitan dengan prosedur penyelesaian matematika. Representasi visual menjadi prasyarat membangun pemodelan matematis (Fitrianna, Dinia, Mayasari, \& Nurhafifah, 2018; Frick, 2019; Joutsenlahti \& Perkkilä, 2019). Selain itu, penyelesaian masalah luas kurva dengan bantuan menggambar grafik meningkatkan kemampuan representasi matematis mahasiswa. Penggambaran grafik sangat membantu dalam menyusun model luas di bawah kurva yang memuat simbol matematis (Septian et al., 2020).

Terdapat alur berpikir dalam mentransformasi poligon menjadi model matematis. Proses ini berdampak dalam menentukan hasil akhir luas daerah di bawah kurva. Proses transformasi dari pertama adalah menerjemahkan daerah bawah kurva sebagai kumpulan persegipanjang. Namun, tidak semua mahasiswa dapat menerjemahkan dengan baik. Demikian pula pada hasil 
penelitian lain bahwa bahwa proses transformasi dilakukan dengan menerjemahkan bentuk representasi. Hal ini bukanlah sesuatu yang mudah. Oleh sebab itu diperlukan pengalaman belajar guna mendukung kemampuan representasi matematis (Rahmawati et al., 2017). Representasi notasi matematis yang tidak baik sebagai hasil terjemahan dari suatu masalah, berdampak pada pemahaman ide matematis. Akibatnya, penyusunan model matematis terasa lebih rumit (Edwards \& Auger-Méthé, 2019).

\section{Simpulan}

Penyelesaian masalah luas daerah di bawah kurva direpresentasikan secara visual maupun simbolik. Representasi penyelesaian secara visual digunakan untuk memudahkan penyusunan model matematis luas daerah di bawah kurva yang memuat simbol-simbol. Terdapat proses berpikir dalam mentransformasi representasi visual menjadi simbolik. Proses ini berperan penting dalam menentukan hasil akhir luas daerah di bawah kurva. Alur berpikir mengenai proses transformasi representasi visual ke simbolik dilakukan melalui tiga tahapan, yakni (1) menafsirkan bentuk visual yaitu menerjemahkan daerah poligon menjadi kumpulan persegi panjang, (2) mengidentifikasi syarat perubahan bentuk visual ke simbolik yaitu menentukan lebar dan panjang partisi daerah poligon, dan (3) membangun representasi simbolik yaitu menentukan luas daerah poligon sebagai kumpulan persegi panjang. Terdapat dua proses yang berbeda dalam menentukan luas daerah poligon sebagai kumpulan persegi panjang, yaitu mahasiswa membuat model matematis dalam bentuk notasi sigma hingga ditemukan hasil akhir, dan melakukan penjumlahan kumpulan luas partisi daerah poligon dengan menggunakan notasi penjumlahan.

Penelitian ini memberikan informasi berkaitan dengan proses menerjemahkan antar bentuk representasi, dalam hal ini adalah transformasi dari representasi visual ke simbolik. Proses penerjemahan ini berupa alur berpikir mahasiswa dalam melakukan penerjemahan gambar kurva menjadi model matematis luas daerah di bawah kurva. Alur berpikir ini dapat digunakan untuk mengantisipasi ternjadinya kesalahan maupun miskonsepsi dalam penyelesaian luas daerah di bawah kurva.

\section{Referensi}

Abdullah, N., Zakaria, E., \& Halim, L. (2012). The effect of a thinking strategy approach through visual representation on achievement and conceptual understanding in solving mathematical word problems. Asian Social Science, 8(16), 30-37. https://doi.org/10.5539/ass.v8n16p30.

Astuti, E. P. (2017). Representasi matematis mahasiswa calon guru dalam menyelesaikan 
masalah matematika. Beta Jurnal Tadris Matematika, 10(1), 70-82. https://doi.org/10.20414/betajtm.v10i1.100.

Boaler, J., Chen, L., Williams, C., \& Cordero, M. (2016). Seeing as understanding: The importance of visual mathematics for our brain and learning. Journal of Applied \& Computational Mathematics, 5(5), 1-6. https://doi.org/10.4172/2168-9679.1000325.

Boonen, A. J. H., Van Wesel, F., Jolles, J., \& Van der Schoot, M. (2014). The role of visual representation type, spatial ability, and reading comprehension in word problem solving: An item-level analysis in elementary school children. International Journal of Educational Research, 68, 15-26. https://doi.org/10.1016/j.ijer.2014.08.001.

Bossé, M., Adu-Gyamfi, K., \& Chandler, K. (2014). Students' differentiated translation processes. International Journal for Mathematics Teaching and Learning.

Bossé, M. J., Adu-Gyamfi, K., \& Cheetham, M. (2011). Translations among mathematical representations: teacher beliefs and practices. International Journal of Mathematics Teaching and Learning, 15(6), 1-23.

Chandler, Adu-Gyamfi, B. (2016). Student connections between algebraic and graphical polynomial representations in the context of a polynomial relation. International Journal of Science and Mathematics Education, 15, 915-938. https://doi.org/10.1007/s10763016-9730-1.

David, M. M., \& Tomaz, V. S. (2012). The role of visual representations for structuring classroom mathematical activity. Educational Studies in Mathematics, 80(3), 413-431. https://doi.org/10.1007/s10649-011-9358-6.

Edwards, A. M., \& Auger-Méthé, M. (2019). Some guidance on using mathematical notation in ecology. Methods in Ecology and Evolution, 10(1), 92-99. https://doi.org/10.1111/2041-210X.13105.

Fitrianna, A. Y., Dinia, S., Mayasari, M., \& Nurhafifah, A. Y. (2018). Mathematical representation ability of senior high school students: an evaluation from students' mathematical disposition. JRAMathEdu (Journal of Research and Advances in Mathematics Education), 3(1), 46. https://doi.org/10.23917/jramathedu.v3i1.5872.

Frick, A. (2019). Spatial transformation abilities and their relation to later mathematics performance. Psychological Research, 83(7), 1465-1484. https://doi.org/10.1007/s00426-018-1008-5.

Fyfe, E. R., McNeil, N. M., Son, J. Y., \& Goldstone, R. L. (2014). Concreteness fading in mathematics and science instruction: A systematic review. Educational Psychology Review, 26(1), 9-25. https://doi.org/10.1007/s 10648-014-9249-3.

Göbel, S. M., Moeller, K., Pixner, S., Kaufmann, L., \& Nuerk, H. (2014). Language affects symbolic arithmetic in children: The case of number word inversion. Journal of Experimental Child, 119, 17-25. https://doi.org/10.1016/j.jecp.2013.10.001.

Huda, U., Musdi, E., \& Nari, N. (2019). Analisis kemampuan representasi matematis siswa dalam menyelesaikan soal pemecahan masalah matematika. Ta'dib, 22(1), 19. https://doi.org/10.31958/jt.v22i1.1226.

Hutagaol, K. (2013). Pembelajaran kontekstual untuk meningkatkan kemampuan representasi matematis siswa sekolah menengah pertama. Infinity Journal, 2(1), 85-99. https://doi.org/10.22460/infinity.v2i1.27.

Ikashaum, F., Mustika, J., Wulantina, E., \& Cahyo, E. D. (2021). Analisis kesalahan representasi simbolik mahasiswa pada soal geometri analitik bidang. Al-Khawarizmi: Jurnal Pendidikan Matematika dan Ilmu Pengetahuan Alam, 9(1), 57-68.

Inglis, M., Attridge, N., \& Batchelor, S. (2011). Non-verbal number acuity correlates with symbolic mathematics achievement: But only in children. Psychonomic Bulletin \& Review, 18, 1222-1229. https://doi.org/10.3758/s13423-011-0154-1.

Joutsenlahti, J., \& Perkkilä, P. (2019). Sustainability development in mathematics education - 
a case study of what kind of meanings do prospective class teachers find for the mathematical symbol "2/3 "? Sustainability (Switzerland), 11(2), 1-15. https://doi.org/10.3390/su11020457.

Komala, E. (2020). Kemampuan representasi simbolik matematik siswa SMP menggunakan blended learning. Jurnal Prisma, 9(2), 204-212. https://doi.org/10.35194/jp.v9i2.1078.

Lestari, K. E., \& Yudhanegara, M. R. (2017). Analisis kemampuan representasi matematis mahasiswa pada mata kuliah geometri transformasi berdasarkan latar belakang pendidikan menengah. Jurnal Matematika Integratif, 13(1), 28-33. https://doi.org/10.24198/jmi.v13.n1.11410.29-34.

Luca, S. D., \& Pesenti, M. (2011). Finger numeral representations: more than just another symbolic code. Fontiers in Psychology, 2(November), 1-3. https://doi.org/10.3389/fpsyg.2011.00272.

Mataheru, W., Huwaa, N. C., \& Matitaputty, C. (2021). Analisis kesalahan mahasiswa dalam perkuliahan matematika dasar secara daring. Jurnal Magister Pendidikan Matematika (JUMADIKA), 3(1), 45-50. https://doi.org/10.30598/jumadikavol3iss1 year2021page45$\underline{50 .}$.

Nurfitriyanti, M., Kusumawardani, R., \& Lestari, I. (2020). Kemampuan representasi matematis peserta didik ditinjau penalaran matematis pada pembelajaran berbasis masalah. Jurnal Gantang, 5(1), 19-28. https://doi.org/10.31629/jg.v5i1.1665.

Rahimah, D. (2012). Identifikasi kesalahan mahasiswa dalam menyelesaikan soal-soal pokok bahasan integral pada mata kuliah kalkulus integral. Exacta, X(1), 89-97.

Rahmawati, D., Purwanto, P., Subanji, S., Hidayanto, E., \& Anwar, R. B. (2017). Process of mathematical representation translation from verbal into graphic. International Electronic Journal of Mathematics Education, 12(4), 367-381.

Sabirin, M. (2014). Representasi dalam pembelajaran matematika. Jurnal Pendidikan Matematika, 1(2), 33-44. https://doi.org/10.18592/jpm.v1i2.49.

Septian, A., Darhim, \& Prabawanto, S. (2020). Geogebra in integral areas to improve mathematical representation ability. Journal of Physics: Conference Series, 1613(1), 012035. https://doi.org/10.1088/1742-6596/1613/1/012035.

Setiawati, F. N., Widadah, S., Nurmala, E., \& Agustina, S. (2020). Representasi matematis siswa SMP berkemampuan tinggi dalam menyelesaikan soal matematika. Indonesian Journal of Mathematics Natural Science Education, 1(2), 111-120. https://doi.org/10.35719/mass.v1i2.35.

Tasman, F., Ahmad, D., \& Suherman, S. (2018). Kesulitan mahasiswa dalam mengkoneksikan sigma, area, dan definisi integral tentu secara geometri. Jurnal Eksakta Pendidikan (Jep), 2(2), 186-193. https://doi.org/10.24036/jep/vol2-iss2/238.

Trance, N. J. C., Marapo, R. B., \& Pornel, J. B. (2012). Students' visual representation of mathematics. Journal of the Korean Association for Science Education, 32(8), 13181332. https://doi.org/10.14697/jkase.2012.32.8.1318.

Utari, R. S., Septy, L., \& Hutauruk, L. (2021). Kesalahan pemahaman konsep peserta didik dalam menyelesaikan soal- soal integral lipat dua pada koordinat polar. Inovasi Matematika (Inomatika), 3(1), 51-61. 